\title{
IMPLEMENTATION OF DISCOVERY LEARNING MODEL TO IMPROVE LEARNING RESULT OF NATURAL SCIENCE AT FIFTH GRADE OF SD KATOLIK ST. PAULUS KEMBES
}

\author{
Stief Aristo Walewangko \\ Universitas Katolik De La Salle, Manado
}

\section{Kata Kunci : \\ Discovery learning model Learning result \\ IPA}

Email penulis:

swalewangko@unikadelasalle. ac.id

\begin{abstract}
This study was intended to describe the application of Discovery Learning Model on natural science subject to improve teacher's skill and learning result of student on fifth grade of Elementary School. This research was classroom action research conducted in two cycles. The collecting data technique was using test and observation. Technique of analyzing data was using quantitive descriptive analysis and qualitative descriptive analysis. These results concluded that the application of Discovery Learning Model can improve the quality of natural science subject learning, such as: teacher's skill and learning result of the fifthgrade student in SD Katolik St. Paulus Kembes. It was suggested that Discovery Learning model can be used as teacher's solution to improve the quality of natural science learning.
\end{abstract}

\begin{abstract}
ABSTRAK
Penelitian ini bertujuan untuk mendeskripsikan penerapan pembelajaran Model Discovery Learning pada mata pelajaran IPA dan meningkatkan hasil belajar siswa kelas V SD. Penelitian ini merupakan Penelitian Tindakan Kelas (PTK) yang terdiri dari dua siklus. Subyek dalam penelitian ini adalah siswa kelas V SD Katolik St. Paulus Kembes.Teknik pengumpulan data menggunakan tes dan observasi. Teknik analisis data menggunakan analisis deskriptif kuantitatif dan analisis deskriptif kualitatif. Berdasarkan hasil-hasil tersebut, maka dapat disimpulkan bahwa pembelajaran model Discovery Learning dapat meningkatkan kualitas pembelajaran IPA yang meliputi keterampilan guru dan hasil belajar siswa kelas V SD Katolik St. Paulus Kembes. Saran dalam penelitian ini adalah agar model Discovery Learning dapat dijadikan acuan guru dan sebagai solusi untuk meningkatkan kualitas pembelajaran IPA.
\end{abstract}

\section{PENDAHULUAN}

Perkembangan peradaban manusia tidak dapat dipisahkan dengan hadirnya pendidikan. Pendidikan yang terjadi secara berkesinambungan bahkan menjadi ciri khas dari perkembangan peradaban manusia (Dewey, 2009:126). Posisi strategis dari pendidikan ini, secara lebih terperinci, dijelaskan dalam Undang-Undang Sistim Pendidikan Nasional Nomor 20 tahun 2003, yakni Pendidikan adalah usaha sadar dan terencana untuk 
mewujudkan suasana belajar dan proses pembelajaran agar peserta didik secara aktif mengembangkan potensi dirinya untuk memiliki kekuatan spiritual keagamaan, pengendalian diri, kepribadian, kecerdasan, akhlak mulia, serta keterampilan yang diperlukan dirinya, masyarakat, bangsa dan Negara.

Dari uraian tersebut jelas ditegaskan bahwa pendidikan merupakan suatu upaya sadar dan terorganisir dengan dasar dan tujuan yang jelas, ada tahapan dan komitmen bersama, direncanakan secara matang dengan sistem pendukung yang telah disiapkan, berlangsung kontinyu (sepanjang hayat), menuju kualitas peserta didik yang manusiawi meliputi keseluruhan aspek/potensi secara utuh dan bulat (aspek fisik-non fisik; emosi-intelektual; kognitif-afektif psikomotor). Dengan kata lain, pendidikan memiliki tujuan yang jelas, yaitu "mencerdaskan kehidupan bangsa dan mengembangkan manusia Indonesia seutuhnya, yaitu manusia yang beriman dan bertakwa kepada Tuhan yang Maha Esa dan berbudi pekerti luhur, memiliki pengetahuan dan nalar, keterampilan, kesehatan jasmani dan rohani, kepribadian yang mantap, serta rasa tanggung jawab dan kebangsaan.”

Dalam keseluruhan proses pendidikan, kegiatan belajar mengajar merupakan kegiatan yang paling pokok. Hal ini berarti bahwa berhasil atau tidaknya pencapaian pendidikan banyak bergantung pada bagaimana proses belajar mengajar dirancang dan dijalankan secara profesional. Setiap proses belajar mengajar mengandaikan keaktifan dari guru dan siswa sebagai komponen dasar dalam pembelajaran. Perpaduan dari kedua komponen dasar ini menghasilkan interaksi edukatif yang saling mempengaruhi satu dengan lainnya. Karena itu, kegiatan belajar-mengajar haruslah merupakan aktifitas yang hidup, sarat akan nilai dan senantiasa memiliki tujuan.

Pada jenjang Sekolah Dasar (SD), proses belajar-mengajar dilaksanakan dengan adanya pelbagai mata pelajaran. Mata pelajaran adalah objek dari proses belajar mengajar, dan karena itu, mata pelajaran pun wajib ada dalam proses belajar mengajar.Salah satu mata pelajaran yang diajarkan pada jenjang SD adalah Ilmu Pengetahuan Alam (IPA). Pembelajaran Ilmu Pengetahuan Alam (IPA) dengan unsur penerapannya dalam kehidupan masyarakat membuat pendidikan IPA menjadi sangat penting. IPA pertama-tama dipandang sebagai produk pengetahuan yang merangsang siswa untuk mengetahui berbagai konsep tentang dunia dan lingkungannya (Iskandar,1997, hlm. 15). Konsep-konsep yang ditawarkan diperoleh melalui suatu proses yang mengandalkan keterampilan.dan pada akhirnya siswa dipacu untuk membentuk sikap ilmiah, kritis dan objektif dalam kehidupan. Hal ini berarti bahwa siswa dituntut untuk terampil,mandiri dan kreatif menemukan sesuatu, berpikir terbuka dan sensitif terhadap lingkungan sekitar. Guru menjadi fasilitator yang mendampingi, membimbing dan mengarahkan siswa untuk mencapai kualitas pengetahuan yang diharapkan.

Namun kenyataannya, berdasarkan hasil observasi dan wawancara yang dilakukan bersama dengan guru mata pelajaran IPA kelas V di SD Katolik St. Paulus Kembes, Kecamatan Tombulu, hasil pembelajaran IPA siswa masih tergolong rendah. Hal ini terlihat dari hasil tes yang dilakukan guru pada ujian semester satu tahun pelajaran 2013-2014 yang hanya mencapai $30 \%$ dari 25 siswa. Hal ini berarti bahwa terdapat $70 \%$ siswa yang belum mencapai standar KKM (Kriteria Ketuntasan Minimal). Standar ketuntasan belajar IPA yang digunakan di sekolah adalah 75. Selain itu, para siswa di dalam kelas terlihat kurang kreatif dan lebih sering menunggu apa yang akan diberikan oleh guru. 
Dalam observasi, ditemukan bahwa kesulitan yang dialami siswa dalam proses pembelajaran IPA kelas V di SD Katolik St. Paulus Kembes disebabkan oleh beberapa faktor, antara lain: a) motivasi belajar IPA siswa rendah; b) siswa cepat menjadi bosan dan tidak bersemangat mengikuti pelajaran IPA; c) kegiatan pembelajaran tidak menarik, cenderung pasif, hanya menerima dan mencatat apa yang diberikan guru tanpa kegiatan mencari dan menemukan sendiri atau mengungkapkan pendapat; d) model pembelajaran yang digunakan guru di dalam kelas masih monoton dan terpusat pada guru (teacher-oriented) sehingga menjadi sangat membosankan; dan e) kualifikasi akademik guru wali kelas V tidak sesuai dengan tugas dan pekerjaannya di dalam kelas.

Lebih lanjut Pembelajaran IPA yang dilaksanakan oleh guru di dalam kelas masih menggunakan metode ceramah. Guru belum sepenuhnya melaksanakan pembelajaran secara aktif dan kreatif dalam melibatkan siswa. Pembelajaran IPA masih didominasi oleh metode ceramah, mencatat buku dan pemberian tugas. Dalam pembelajaran, guru masih terpaku pada buku teks sebagai satu-satunya sumber mengajar. Keberhasilan siswa dalam belajar hanya dilihat dari hasil tes atau ujian. Belajar seolah-olah hanya untuk kepentingan menghadapi ujian telepas dari permasalahan-permasalahan kehidupan sehari-hari. akibatnya, siswa hanya menghafal konsep-konsep, teori-teori, rumus-rumus yang susah, tanpa ada pemahaman terhadap pengetahuan itu sendiri. Dengan kata lain, pembelajaran IPA di dalam kelas belum sesuai dengan dimensi IPA yang sesungguhnya yaitu IPA sebagai produk dan proses, sehingga pengetahuan tersebut ditemukan sendiri oleh siswa. Siswa menemukan sendiri pengetahuannya dengan maksud siswa dilibatkan sepenuhnya dalam pembelajaran dan dilatih untuk menggali dan mengolah informasi, mengambil keputusan secara tepat, memecahkan masalah, sehingga pembelajarannya menjadi lebih bermakna.

Untuk itu, peneliti merasa perlu untuk melakukan perubahan dalam proses pembelajaran IPA pada siswa kelas V di SD Katolik St. Paulus Kembes. Peneliti memandang perlu untuk mengubah paradigma lama dan mengatasi kelemahan-kelemahan pembelajaran tersebut. Salah satu model pembelajaran yang menekankan keaktifan siswa dalam menemukan konsep sendiri adalah model Discovery Learning. Pada model ini siswa dituntun untuk membangun pengetahuan mereka sendiri dengan mengadakan suatu percobaan dan menemukan sebuah prinsip dari hasil percobaan tersebut. Discovery Learning merupakan komponen dari praktek pendidikan yang meliputi metode mengajar yang memajukan cara belajar aktif, berorientasi pada proses, mengarahkan sendiri dan reflektif (Suryosubroto, 2012, hlm.192).

Berdasarkan latar belakang di atas, maka dalam Penelitian Tindakan Kelas ini penulis memilih judul "Penerapan Model Discovery Learning Untuk Meningkatkan Hasil Belajar IPA Siswa Kelas V SD Katolik St. Paulus Kembes.”. Model Discovery Learning atau Pembelajaran Berbasis Penemuan didefinisikan sebagai proses pembelajaran yang terjadi bila para siswa tidak disajikan dengan pelajaran dalam bentuk finalnya, tetapi diharapkan siswa mengorganisasi sendiri, sebagaimana pendapat Bruner, bahwa: "Discovery Learning can be defined as the learning that takes place when the student is not presented with subject matter in the final form, but rather is required to organize it him self" Lefancois (dalam Emetembun, 1986, hlm. 103). Ide dasar Bruner ialah pendapat dari Piaget yang menyatakan bahwa anak harus berperan aktif dalam belajar di kelas.

Model Discovery Learning adalah memahami konsep, arti dan hubungan, melalui proses intuitif untuk akhirnya sampai kepada suatu kesimpulan (Budiningsih, 2005, hlm. 43). Discovery terjadi bila individu terlibat, terutama dalam penggunaan proses mentalnya untuk 
menemukan beberapa konsep dan prinsip. Senada dengan hal itu, Suryosubroto (2002, hlm. 192) menjelaskan bahwa Discovery Learning merupakan komponen dari praktek pendidikan yang meliputi metode mengajar yang memajukan cara belajar aktif, berorientasi pada proses, mengarahkan sendiri dan reflektif. Discovery dilakukan melalalui observasi, klarifikasi, pengukuran, prediksi, penentuan dan inferi. Proses tersebut disebut cognitive process sedangkan discovery itu sendiri adalah the mental process of assimilating concept and principles in the mind Robert B. Sund (dalam Malik, 2001, hlm. 219).

Lebih lanjut, di dalam proses belajar, Bruner mementingkan partisipasi aktif dari tiap siswa, dan mengenal dengan baik adanya perbedaan kemampuan. Untuk menunjang proses belajar perlu lingkungan yang memfasilitasi rasa ingin tahu siswa pada tahap eksplorasi. Lingungan ini dinamakan Discovery Learning Environment, yaitu lingkungan di mana siswa dapat melakukan eksplorasi, penemuan-penemuan baru yang belum dikenal atau pengertian yang mirip dengan yang sudah diketahui. Lingkungan seperti ini bertujuan agar siswa dapat belajar dengan baik dan kreatif dalam proses belajar-mengajar.

Dalam mengaplikasikan model pembelajaran Discovery Learning guru berperan sebagai pembimbing dengan memberikan kesempatan kepada siswa untuk belajar secara aktif, sebagaimana pendapat bahwa guru harus dapat membimbing dan mengarahkan kegiatan belajar siswa sesuai dengan tujuan. Kondisi seperti ini ingin merubah kegiatan belajar mengajar yang teacher-oriented menjadi student oriented. Dengan kata lain, guru memberi kesempatan kepada para siswa untuk menjadi problem solver, seorang scientist, historin, atau ahli matematika. Hal ini menjadi mungkin karena bahan ajar tidak diberikan dalam bentuk final, dan siswa harus menghimpun informasi, membandingkan, mengkategorisasi, menganalisis, mengintegrasi dan membuat kesimpulan-kesimpulan.

Melalui uraian di atas, dapat disimpulkan bahwa Model Discovery Learning adalah model pembelajaran yang memberi kesempatan kepada siswa untuk secara aktif dan kreatif menemukan pengetahuan mereka sendiri dengan melakukan proses ilmiah: membuat observasi, menghimpun informasi, membandingkan, mengkategorisasi, menganalisis, bereksperimen, dan membuat kesimpulan-kesimpulan. Karena itu, dalam Model Discovery Learning aktifitas mental dan fisik siswa sangat ditekankan.

Model Discovery Learning memiliki karakteristik/ciri-ciri yang khas dan membedakan dengan beberapa model yang lain. Karakteristik Discovery learning adalah (Syah, 2004, hlm. 240):

a. Model pembelajaran ini merupakan salah satu bagian dari model pembelajaran penemuan yang banyak melibatkan peserta didik dalam kegiatan belajar mengajar.

b. Model ini merupakan kombinasi antara pembelajaran langsung dan pembelajaran tidak langsung.

c. Adanya hubungan yang kuat antara dominasi guru dan kesiapan metal peserta didik.

d. Pembelajaran yang menempatkan peserta didik sebagai pelaksana sedangkan guru hanya bertindak sebagai fasilitator

e. Pembelajaran yang lebih menitik-beratkan pada pemecahan masalah oleh peserta didik dengan bimbingan guru.

Berdasarkan fakta dan hasil pengamatan, penerapan model Discovery Learning dalam pembelajaran memiliki keunggulan-keunggulan dan kelemahan-kelemahan (Syah, 2004, hlm. 242). Keunggulan model ini adalah: 
1) Membantu siswa untuk memperbaiki dan meningkatkan keterampilan-keterampilan dan proses-proses kognitif. Usaha penemuan merupakan kunci dalam proses ini, tergantung bagaimana cara belajar seseorang.

2) Pengetahuan yang diperoleh melalui model ini sangat pribadi dan ampuh karena menguatkan pengertian, ingatan dan transfer.

3) Menimbulkan rasa senang pada siswa karena tumbuhnya rasa ingin menyelidiki dan berhasil.

4) Menyebabkan siswa mengarahkan kegiatan belanjarnya sendiri dengan melibatkan akal dan motivasinya.

5) Model ini memungkinkan siswa berkembang dengan cepat sesuai dengan kecepatannya sendiri.

6) Membantu siswa memperkuat konsep dirinya, karena memperoleh kepercayaan bekerja sama dengan yang lainnya.

7) Berpusat pada siswa dan guru berperan sama-sama aktif mengeluarkan gagasan-gagasan, bahkan gurupun dapat bertindak sebagai siswa dan peneliti di dalam situasi diskusi.

8) Membantu siswa menghilangkan skeptisme (keragu-raguan) karena mengarah pada kebenaran yang final, tertentu dan pasti.

9) Siswa akan mengerti konsep dasar dan ide-ide dengan lebih baik.

10) Membantu dan mengembangkan ingatan dan transfer kepada situasi proses belajar yang baru.

11) Menodorong siswa berpikir dan bekerja atas inisiatif sendiri.

12) Memberikan keputusan yang bersifat intrinsik.

13) Situasi proses belajar menjadi lebih terangsang.

14) Proses belajar meliputi semua aspek siswa menuju pada pembentukan manusia seutuhnya.

15) Meningkatkan tingkat penghargaan diri siswa.

16) Kemungkinan siswa belajar dengan memanfaatkan berbagai jenis sumber belajar.

17) Dapat mengembangkan bakat dan kecakapan individu.

Sedangkan kelemahan model discovery learning adalah:

1) Menimbulkan asumsi bahwa ada kesiapan pikiran untuk belajar. Bagi siswa yang kurang pandai akan mengalami kesulitan dalam hal berpikir abstrak atau mengungkapkan hubungan antara konsep-konsep, yang tertulis atau lisan, sehingga dapat menimbulkan rasa frustasi.

2) Tidak efisien untuk mengajar jumlah siswa yang banyak, karena membutuhkan waktu yang lama untuk membantu mereka menemukan teori dan pemecahan masalah lainnya.

3) Harapan-harapan yang terkandung dalam model ini dapat buyar berhadapan dengan siswa dan guru yang telah terbiasa dengan cara-cara belajar yang lama.

4) Discovery learning lebih cocok untuk mengembangkan pemahaman, sedangkan mengembangkan aspek konsep, keterampilan dan emosi secara keseluruhan kurang mendapat perhatian.

5) Tidak menyediakan kesempatan-kesempatan untuk berpikir yang akan ditemukan oleh siswa karena telah dipilih terlebih dahulu oleh guru.

6) Kurangnya fasilitas untuk mengukur gagasan-gagasan yang dikemukakan oleh siswa.

Model discovery learning dilaksanakan dalam pembelajaran menurut beberapa langkah, antara lain (Syah, 2004, hlm. 244) :

1) Stimulation (stimulasi/pemberian rangsangan)

Pertama-tama pada tahap ini pelajar dihadapkan pada sesuatu yang menimbulkan kebingungannya, kemudian dilanjutkan untuk tidak memberi generalisasi agar timbul 
keinginan untuk menyelidiki sendiri. Di samping itu, guru dapat memulai kegiatan proses belajar mengajar dengan mengajukan pertanyaan, anjuran membaca buku, dan aktifitas belajar lainnya yang mengarah pada persiapan pemecahan masalah.

2) Problem Statement (pernyataan/identifikasi masalah)

Setelah dilakukan stimulasi, langkah selanjutnya adalah guru memberikan kesempatan kepada siswa untuk mengidentifikasi sebanyak mungkin agenda-agenda masalah yang relevan dengan bahan pelajaran, kemudian salah satunya dipilih dan dirumuskan dalam bentuk hipotesis (jawaban sementara atas pernyataan masalah) (Syah, 2004, hlm. 244). Permasalahan yang dipilih itu selanjutnya harus dirumuskan dalam bentuk pertanyaan, atau hipotesis.

3) Data Collection (pengumpulan data)

Ketika eksplorasi berlangsung, guru juga memberi kesempatan kepada para siswa untuk mengumpulkan informasi sebanyak-banyaknya yang relevan untuk membuktikan benar atau tidaknya hipotesis (Syah, 2004, hlm. 244). Tahap ini berfungsi untuk menjawab pertanyaan atau membuktikan benar tidaknya hipotesis, dengan demikian anak didik diberi kesempatan untuk mengumpulkan (collection) berbagai informasi yang relevan, membaca literatur, mengamati objek, wawancara dengan nara sumber, melakukan uji coba sendiri dan sebagainya.

4. Data Processing (pengolahan data)

Semua informasi hasil bacaan, wawancara, observasi dan sebagainya semuanya diolah, diacak, diklasifikasikan, ditabulasi, bahkan bila perlu dihitung dengan cara tertentu serta ditafsirkan pada tingkat kepercayaan tertentu (Djamarah 2002, hlm. 22). Pengolahan data merupakan kegiatan mengolah data dan informasi yang telah diperoleh para siswa baik melalui wawancara, observasi, dan sebagainya; lalu kemudian ditafsirkan (Syah, 2004, hlm. 244).

5) Verification (pembuktian)

Pada tahap ini siswa melakukan pemeriksaan secara cermat untuk membuktikan benar atau tidaknya hipotesis yang ditetapkan tadi dengan temuan alternative dihubungkan dengan hasil data processing (Syah, 2004, hlm. 244). Verification, menurut Bruner bertujuan agar proses belajar akan berjalan dengan baik dan kreatif jika guru memberikan kesempatan kepada siswa untuk menemukan suatu konsep, teori, aturan atau pemahaman melalui contoh-contoh yang ia jumpai dalam kehidupan.

6) Generalization (menarik kesimpulan/generalisasi)

Tahap generalisasi/menarik kesimpulan adalah proses menarik sebuah kesimpulan yang dapat dijadikan prinsip umum dan berlaku untuk semua kejadian atau masalah yang sama dengan memperhatikan hasil verifikasi (Syah, 2004, hlm. 244). Berdasarkan verifikasi maka dirumuskan prinsip-prinsip yang mendasari generalisasi.

Belajar diartikan sebagai suatu proses usaha yang dilakukan individu untuk memperoleh suatu perubahan tingkah laku yang baru secara keseluruhan sebagai hasil pengalaman individu itu sendiri dalam interaksinya dengan lingkungannya (Slameto, 2003, hlm. 2). Pandangan ini senada dengan pengertian yang diungkapkan oleh Winkel. Winkel yakin bahwa belajar melibatkan aktifitas mental/psikis yang berlangsung dalam interaksi dengan lingkungan yang menghasilkan pengetahuan-pengetahuan, keterampilan, nilai dan sikap serta perubahan itu bersifat relatif konstan dan berbekas (Winkel, 1984, hlm. 136).

Selanjutnya, belajar juga diartikan sebagai belajar modifikasi atau memperteguh kelakuan melalui pengalaman (Hamalik, 2003, hlm 154). Belajar berkaitan dengan perubahan tingkah laku pada diri individu berkat adanya interaksi individu dengan individu dan individu dengan lingkungannya sehingga mereka lebih mampu berinteraksi dengan lingkungannya (Usman, 
1993, hlm. 4). Pendapat lain dikemukakan oleh Sudjana (1991, hlm. 5) bahwa belajar adalah suatu perubahan yang relatif permanen dalam suatu kecenderungan tingkah laku sebagai hasil dari praktek atau latihan.

Hal yang sama ditegaskan oleh Hilgard (dalam Sanjaya, 2006, hlm. 112). Bagi Hilgard belajar itu adalah proses perubahan melalui kegiatan atau prosedur latihan, baik latihan di dalam laboratorium maupun dalam lingkungan alamiah. Belajar bukanlah sekedar mengumpulkan pengetahuan. Belajar adalah proses mental yang terjadi dalam diri seseorang, sehingga menyebabkan munculnya perubahan perilaku. Aktivitas mental itu terjadi karena adanya interaksi individu dengan lingkungan yang disadari.

Berdasarkan beberapa definisi belajar di atas maka dapat dirumuskan definisi belajar yaitu segenap rangkaian kegiatan atau aktifitas yang dilakukan secara sadar oleh seseorang dan mengakibatkan perubahan dalam dirinya berupa penambahan pengetahuan atau kemahiran berdasarkan pengalaman atau interaksinya dengan lingkungan.Perubahan yang terjadi dapat berupa perubahan-perubahan dalam kebiasaan (habit), kecakapan-kecakapan (skill), atau dalam ketiga aspek yakni pengetahuan (kognitif), sikap (afektif) dan keterampilan dasar (Psikomotor).

Hasil belajar merupakan tujuan akhir dilaksanakannya kegiatan pembelajaran di sekolah. Hasil belajar dapat ditingkatkan melalui usaha sadar yang dilakukan secara sistematis mengarah kepada perubahan yang positif yang kemudian disebut dengan proses belajar. Akhir dari proses belajar adalah perolehan suatu hasil belajar siswa. Hasil belajar siswa di kelas terkumpul dalam himpunan hasil belajar kelas.Semua hasil belajar tersebut merupakan hasil dari suatu interaksi tindak belajar dan tindak mengajar. Dari sisi guru, tindak mengajar diakhiri dengan proses evaluasi hasil belajar, sedangkan dari sisi siswa, hasil belajar merupakan berakhirnya penggal dan puncak proses belajar (Dimyati dan Mudjiono, 2009, hlm. 3).

Selanjutnya, hasil belajar juga dimengerti sebagai kemampuan yang dimiliki siswa setelah menerima pengalaman belajar (Sudjana, 2010, hlm. 22). Warsito (dalam Depdiknas, 2006, hlm. 125) mengemukakan bahwa hasil dari kegiatan belajar ditandai dengan adanya perubahan perilaku ke arah positif yang relatif permanen pada diri orang yang belajar. Sesorang dapat dikatakan telah berhasil dalam belajar jika ia mampu menunjukkan adanya perubahan dalam dirinya. Perubahan-perubahan tersebut di antaranya dari segi kemampuan berpikirnya, keterampilannya, atau sikapnya terhadap suatu objek (Wahidmurni, dkk, 2010, hlm. 18).

Jika dikaji lebih mendalam, maka hasil belajar dapat tertuang dalam taksonomi Bloom, yakni dikelompokkan dalam tiga ranah (domain) yaitu domain kognitif atau kemampuan berpikir, domain afektif atau sikap, dan domain psikomotor atau keterampilan. Sehubungan dengan itu, Gagne (dalam Sudjana, 2010, hlm. 22) menjelaskan tentang kemampuan hasil belajar menjadi lima macam, yaitu:

"1) hasil belajar intelektual merupakan hasil belajar terpenting dari sistem lingsikolastik; 2) strategi kognitif yaitu mengatur cara belajar dan berfikir seseorang dalam arti seluas-luasnya termaksuk kemampuan memecahkan masalah; 3) sikap dan nilai, berhubungan dengan arah intensitas emosional dimiliki seseorang sebagaimana disimpulkan dari kecenderungan bertingkah laku terhadap orang dan kejadian; 4) informasi verbal, pengetahuan dalam arti informasi dan fakta; dan 5) keterampilan motorik yaitu kecakapan yang berfungsi untuk lingkungan hidup serta memprestasikan konsep dan lambang." 
Untuk mengetahui hasil belajar seseorang dapat dilakukan dengan melakukan tes dan pengukuran. Tes dan pengukuran memerlukan alat sebagai pengumpul data yang disebut dengan instrumen penilaian hasil belajar. Instrumen dibagi menjadi dua bagian besar, yakni tes dan non tes (Wahidmurni, dkk, 2010, hlm. 28). Gambaran bahwa hasil belajar yang diperoleh dapat diukur melalui kemajuan yang diperoleh siswa setelah belajar dengan sungguh-sungguh (Hamalik, 2006, hlm. 155). Hasil belajar tampak terjadinya perubahan tingkah laku pada diri siswa yang dapat diamati dan diukur melalui perubahan sikap dan keterampilan.Perubahan tersebut dapat diartikan terjadinya peningkatan dan pengembangan yang lebih baik dibandingkan dengan sebelumnya.

Berdasarkan konsepsi di atas, dapat disimpulkan bahwa hasil belajar dimengerti sebagai perubahan perilaku secara positif serta kemampuan yang dimiliki siswa dari suatu interaksi tindak belajar dan mengajar yang berupa hasil belajar intelektual, strategi kognitif, sikap dan nilai, inovasi verbal, dan hasil belajar motorik.

Faktor-faktor yang mempengaruhi hasil belajar dikelompokkan dalam dua jenis, yakni faktor intern dan faktor ekstern (Slameto, 2010, hlm. 54). Faktor intern adalah faktor yang ada di dalam diri individu yang sedang belajar, sedangkan faktor ekstern adalah faktor luaran yang terdapat di luar individu tersebut.

a. Faktor-faktor interen meliputi:

1) Faktor jasmaniah, sangat berpengaruh pada proses belajar seseorang. Artinya kesehatan seseorang berpengaruh terhadap belajarnya. Proses belajar seseorang akan terganggu jika kesehatan seseorang terganggu. Selain itu juga ia akan cepat lelah, kurang bersemangat, mudah pusing, mengantuk jika badannya lemah, kurang darah ataupun ada gangguan-gangguan fungsi alat inderanya serta tubunya. Begitupun dengan kondisi cacat tubuh anak akan mempengaruhi belajarnya.

2) Faktor psikologis, sekurang-kurangnya ada tujuh faktor yang tergolong dalam faktor psikologis yang mempengaruhi belajar. Faktor-faktor tersebut adalah: intelegensi, perhatian, minat, bakat, motif, kematangan dan kelelahan.

3) Faktor kelelalan, kelelahan pada seseorang walaupun sulit untuk dipisahkan tetapi dapat dibedakan menjadi dua macam, yakni kelelahan jasmani dan kelelahan rohani (bersifat psikis). Tubuh yang mengalami kelelahan baik kelelahan jasmani maupun kelelahan rohani dapat mempengaruhi belajar.

b. Faktor-faktor ekstern meliputi:

1) Faktor keluarga, siswa yang belajar akan menerima pengaruh dari keluarga berupa cara orang tua mendidik, relasi antara anggota keluarga, suasana rumah tangga dan keadaan ekonomi keluarga.

2) Faktor sekolah, mempengaruhi belajar ini mencakup metode pengajar, kurikulum, relasi guru dengan siswa, relasi siswa dengan siswa, disiplin sekolah, pelajaran dan waktu sekolah, standar pelajaran, keadaan gedung, metode belajar dan tugas rumah.

3) Faktor masyarakat, merupakan faktor ekstern yang juga berpengaruh terhadap belajar siswa. Pengaruh itu terjadi karena keberadaannya siswa di dalam masyarakat. Kegiatan siswa dalam masyarakat, mass media, teman bergaul dan bentuk kehidupan masyarakat, semuanya mempengaruhi belajar.

IPA atau Ilmu Pengetahuan Alam dari segi istilah dapat diartikan sebagai ilmu yang berisi pengetahuan alam. Ilmu artinya pengetahuan yang benar,yaitu bersifat rasional dan obyektif. Pengetahuan alam adalah pengetahuan yang berisi tentang alam semesta dan segala isinya. IPA adalah pengetahuan yang rasional dan obyektif tentang alam semesta dan segala isinya (Darmojo dan Kaligis, 1992, hlm. 3). 
Istilah Ilmu Pengetahuan Alam atau IPA dikenal juga dengan istilah sains. Kata sains ini berasal dari bahasa latin yaitu 'scientia' yang berarti 'pengetahuan'. Dalam bahasa inggris, kata sains berasal dari kata 'science' yang berarti 'pengetahuan'. Science kemudian berkembang menjadi social science yang dalam bahasa indonesia dikenal dengan ilmu pengetahuan sosial (IPS) dan natural science yang dalam bahasa indonesia dikenal dengan ilmu pengetahuan alam (IPA). Fowler (dalam Trianto, 2012, hlm. 136) mendefinisikan natural science sebagai systematic and formulated knowledge dealing with material phenomena and based mainly on observation and induction. Ilmu Pengetahuan Alam dimengerti sebagai pengetahuan yang sistematis dan disusun dengan menghubungkan gejala-gejala alam yang bersifat kebendaan dan didasarkan pada hasil pengamatan dan induksi.

IPA merupakan cabang pengetahuan yang berawal dari fenomena alam. IPA didefinisikan sebagai sekumpulan pengetahuan tentang objek dan fenomena alam yang diperoleh dari hasil pemikiran dan penyelidikan ilmuwan yang dilakukan dengan keterampilan bereksperimen dengan menggunakan metode ilmiah. IPA pada dasarnya merupakan ilmu pengetahuan tentang gejala alam yang dituangkan berupa fakta, konsep, prinsip dan hukum yang teruji kebenaranya dan melalui suatu rangkaian kegiatan dalam metode ilmiah. IPA merujuk pada sebuah proses sistematis untuk mendapat informasi tentang alam, yang berupa pengetahuan, di mana proses yang dimaksud dilaksanakan secara ilmiah dan dapat dipertanggungjawabkan (Abruscato, dkk., 2010, hlm. 6).

Beberapa pendapat di atas menegaskan bahwa IPA (Ilmu Pengetahuan Alam) merupakan suatu ilmu teoritis, akan tetapi teori tersebut didasarkan atas pengamatan, percobaanpercobaan pada gejala-gejala alam. Meskipun suatu teori dirumuskan dengan sangat bagus, tidaklah dapat dipertahankan kalau tidak sesuai dengan hasil-hasil pengamatan atau observasi. Fakta-fakta tentang gejala kebendaan atau alam diselidiki dan diuji berulangulang melalui percobaan-percobaan (eksperimen), kemudian berdasarkan hasil dari eksperimen itulah dirumuskan keterangan ilmiahnya (teorinya) (Abdulah dan Eny, 2009, hlm. 16). Teori pun tidak dapat berdiri sendiri, teori selalu di dasari oleh suatu hasil pengamatan.

Dengan demikian, dapat disimpulkan bahwa Pengertian IPA (Ilmu Pengetahuan Alam) adalah suatu pengetahuan teoritis yang diperoleh atau disusun dengan cara yang khas atau khusus, yaitu melakukan observasi eksperimentasi, penyusunan teori, penyimpulan, eksperimentasi, verifikasi, observasi dan demikian seterusnya kait-mengkait antara cara yang satu dengan cara yang lain. Cara untuk mendapatkan ilmu secara demikian ini terkenal dengan nama metode ilmiah. Pada dasarnya metode ilmiah merupakan suatu cara yang logis untuk memecahkan suatu masalah tertentu.

\section{METODE PENELITIAN}

Metode penelitian ini adalah Penelitian Tindakan Kelas (PTK). Desain Penelitian ini menggunakan Penelitian Tindakan Kelas model Action Research Kemmis dan Taggart (dalam Ekawarna, 2013, hlm. 20), yang terdiri dari 4 tahap, yakni 1) membuat perencanaan, 2) melakukan tindakan, 3) melaksanakan observasi, 4) melakukan refleksi dengan dua siklus. Untuk lebih jelasnya, alur penelitian seperti gambar berikut: 


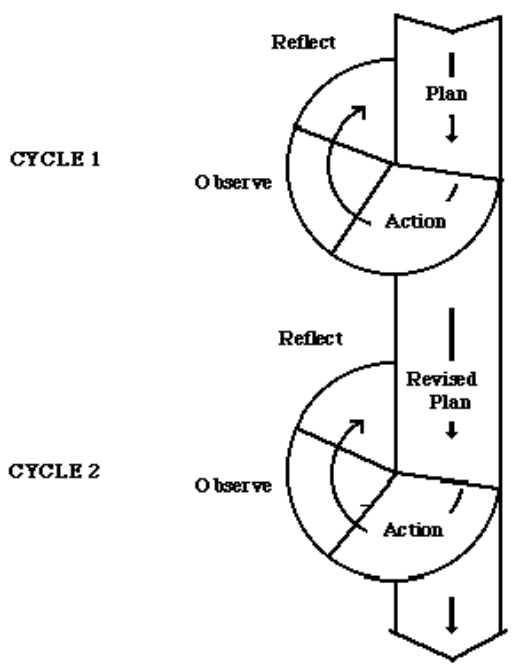

Gambar 1. Rancangan Pelaksanaan Penelitian Melalui 2 Siklus (Ekawarna, 2013, hlm. 20)

Penelitian tindakan kelas terdiri dari beberapa siklus, bisa 2 siklus atau lebih. Sehubungan dengan itu, penelitian tindakan kelas ini akan dilaksanakan melalui dua siklus untuk melihat peningkatan hasil belajar siswa dalam mengikuti mata pelajaran Ilmu Pengetahuan Alam melalui Model Discovery Learning.

Penelitian Tindakan Kelas ini dilaksanakan di SD Katolik St. Paulus Kembes Kecamatan Tombulu Kabupaten Minahasa untuk mata pelajaran Ilmu Pengetahuan Alam. Sebagai subjek dalam penelitian ini adalah kelas V Tahun Pelajaran 2014-2015 dengan jumlah siswa sebanyak 25, yang terdiri dari 12 siswa laki-laki dan 13 siswa perempuan. Pemilihan sekolah ini dalam rangka: 1) Memperbaiki dan meningkatkan proses pembelajaran di SD Katolik St. Paulus Kembes; 2) Memperoleh umpan balik dari guru dalam proses pelaksanaan kurikulum 2013 di SD Katolik St. Paulus Kembes, khususnya pada mata pelajaran Ilmu Pengetahuan Alam; dan 3) Memperbaiki dan meningkatkan hasil belajar siswa di SD Katolik St. Paulus Kembes. Teknik pengumpulan data dalam penelitian ini adalah tes, observasi dan wawancara.

Untuk menganalisis hasil belajar siswa dapat dilihat dari tes tertulis individu sesudah pembelajaran diterapkan. Setelah itu ditentukan/dihitung nilai rata-rata kelas pada akhir siklus I dan II, dengan membuat pengelompokkan rentang ketuntasan belajar. Indikator kuantitatif pembelajaran IPA dalam penelitian ini dinyatakan berhasil apabila hasil belajar IPA kelas V SD Katolis St. Paulus Kembes mencapai nilai 75 (Sesuai dengan KKM mata pelajaran IPA di sekolah tersebut). Untuk menghitung nilai rata-rata kelas pada setiap akhir siklus digunakan rumus sederhana berikut:

Nilai Siswa $T$

$$
\mathrm{KB}=\frac{\mathrm{T}}{\mathrm{Tt}} \times 100 \%
$$

Keterangan:

$\mathrm{KB}=$ Ketuntasan Belajar

$\mathrm{T}=$ Jumlah skor yang diperoleh siswa

$\mathrm{Tt}=$ Jumlah Skor Total

(Trianto, 2011, hlm. 63-64)

Adapun penggolongan rentang ketuntasan belajar adalah sebagai berikut:

$90-100 \% \quad: \quad$ Baik Sekali

$75-89 \% \quad$ : Baik 


$\begin{array}{lll}50-74 \% & : & \text { Cukup } \\ 30-49 \% & : & \text { Kurang } \\ 0-29 & : & \text { Sangat Kurang }\end{array}$

\section{HASIL DAN PEMBAHASAN}

\section{HASIL SIKLUS I}

Pada siklus I hal yang diamati adalah mengenai keterampilan guru dalam menerapkan model discovery learning dan hasil belajar siswa kelas V SD Katolik St. Paulus Kembes. Menurut hasil yang telah dipaparkan di atas, keterampilan guru dalam menggunakan model discovery learning adalah sebesar 71,42\% dengan kriteria Baik. hal ini dapat dilihat dalam tabel dan diagram berikut:

\begin{tabular}{|c|l|c|}
\hline No. & \multicolumn{1}{|c|}{ Aspek yang diamati } & Nilai \\
\hline 1. & Keterampilan menstimulasi siswa dalam pembelajaran (Stimulation) & 4 \\
\hline 2. & $\begin{array}{l}\text { Keterampilan membimbing siswa untuk membuat hipotesis tentang } \\
\text { materi pembelajaran yang sedang didalami (problem statement) }\end{array}$ & 3 \\
\hline 3. & $\begin{array}{l}\text { Keterampilan membimbing siswa dalam menemukan data-data dalam } \\
\text { pembelajaran (data collection) }\end{array}$ & 4 \\
\hline 4. & $\begin{array}{l}\text { Keterampilan membimbing siswa dalam mengolah data yang ditemukan } \\
\text { (data processing) }\end{array}$ & 4 \\
\hline 5. & $\begin{array}{l}\text { Keterampilan membimbing siswa membuktikan temuan data yang } \\
\text { diperoleh (verification) }\end{array}$ & 3 \\
\hline 6. & $\begin{array}{l}\text { Keterampilan membimbing siswa membuat kesimpulan dari data yang } \\
\text { diperoleh (generalization) }\end{array}$ & 3 \\
\hline 7. & Keterampilan membimbing siswa menyampaikan ide/gagasan/kesimpulan & 3 \\
\hline & \multicolumn{1}{|c|}{ Jumlah Skor Total } & $\mathbf{2 5}$ \\
\hline
\end{tabular}

Tabel 1. Data Hasil Observasi Guru Siklus 1

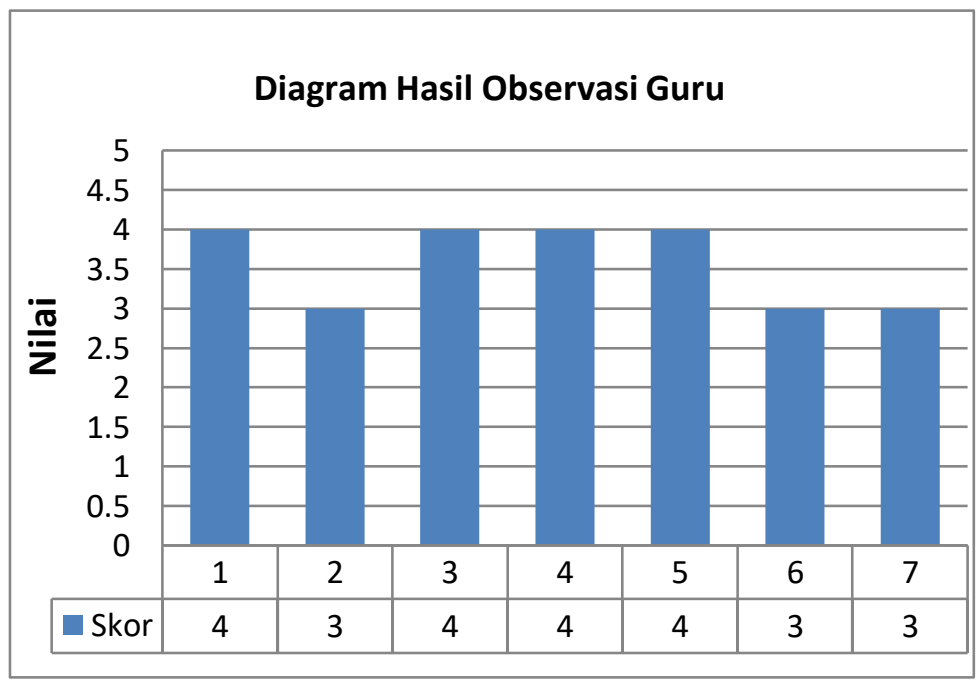

Gambar 2. Diagram Hasil Observasi Guru Siklus I

Berdasarkan hasil observasi tersebut maka nilai skor dan persentasi hasil observasi yang dilakukan oleh guru pamong (kolaborator) adalah Jumlah skor observasi/jumlah skor total $\mathrm{x}$ $100 \%$, yakni: $25 / 35 \times 100 \%=71,42 \%$. Menurut persentasi di atas, keterampilan guru dalam menggunakan model Discovery Learning pada Siklus I mendapat kriteria 'Baik'. 
Berikutnya, hasil belajar siswa pada siklus I. nilai skor dan persentasi hasil belajar siswa adalah 1730/2500 x 100\% =69,20\%. Secara keseluruhan, hasil belajar siswa dalam pembelajaran IPA melalui penerapan model discovery learning diperoleh sebagai berikut:

\begin{tabular}{|c|l|c|}
\hline No & \multicolumn{1}{|c|}{ Aspek } & Pencapaian \\
\hline 1 & Nilai rata-rata yang dicapai & 69,2 \\
\hline 2 & Nilai terendah & 50 \\
\hline 3 & Nilai tertinggi & 88 \\
\hline 4 & Jumlah siswa tuntas & 10 \\
\hline 5 & Jumlah siswa tidak tuntas & 15 \\
\hline
\end{tabular}

Tabel 2. Rekapitulasi hasil belajar siklus I

Selengkapnya data hasil belajar siswa dapat dilihat dalam tabel berikut ini:

\begin{tabular}{|c|l|c|c|c|c|c|c|c|c|c|c|c|}
\hline \multirow{2}{*}{ No } & Kode & \multicolumn{8}{|c|}{ Skor mentah } & \multirow{2}{*}{ Skor } & \multirow{2}{*}{ Nilai } \\
\cline { 3 - 11 } & Siswa & $\mathbf{1}$ & $\mathbf{2}$ & $\mathbf{3}$ & $\mathbf{4}$ & $\mathbf{5}$ & $\mathbf{6}$ & $\mathbf{7}$ & $\mathbf{8}$ & $\mathbf{9}$ & & \\
\hline 1 & S1 & 1 & 1 & 0 & 0 & 0 & 3 & 3 & 3 & 4 & 15 & 60 \\
\hline 2 & S2 & 0 & 1 & 1 & 0 & 0 & 2 & 4 & 4 & 2 & 14 & 56 \\
\hline 3 & S3 & 1 & 1 & 1 & 0 & 1 & 3 & 4 & 4 & 4 & 19 & 76 \\
\hline 4 & S4 & 1 & 1 & 1 & 1 & 1 & 5 & 4 & 4 & 4 & 22 & 88 \\
\hline 5 & S5 & 1 & 0 & 1 & 1 & 1 & 3 & 4 & 4 & 4 & 19 & 76 \\
\hline 6 & S6 & 0 & 1 & 1 & 1 & 1 & 3 & 4 & 3 & 3 & 17 & 68 \\
\hline 7 & S7 & 1 & 1 & 1 & 0 & 0 & 3 & 4 & 3 & 3 & 16 & 64 \\
\hline 8 & S8 & 0 & 1 & 0 & 1 & 0 & 3 & 3 & 4 & 3 & 15 & 60 \\
\hline 9 & S9 & 1 & 1 & 1 & 1 & 0 & 4 & 4 & 5 & 4 & 21 & 84 \\
\hline 10 & S10 & 1 & 1 & 1 & 1 & 1 & 4 & 4 & 3 & 4 & 20 & 80 \\
\hline 11 & S11 & 1 & 1 & 0 & 0 & 1 & 3 & 3 & 3 & 4 & 15 & 50 \\
\hline 12 & S12 & 1 & 1 & 1 & 1 & 1 & 3 & 3 & 4 & 4 & 19 & 76 \\
\hline 13 & S13 & 0 & 1 & 0 & 1 & 1 & 4 & 4 & 5 & 4 & 20 & 80 \\
\hline 14 & S14 & 1 & 1 & 1 & 1 & 1 & 3 & 3 & 3 & 4 & 13 & 84 \\
\hline 15 & S15 & 0 & 0 & 1 & 1 & 0 & 2 & 3 & 4 & 3 & 14 & 56 \\
\hline 16 & S16 & 0 & 0 & 0 & 1 & 1 & 3 & 3 & 3 & 3 & 14 & 56 \\
\hline 17 & S17 & 1 & 1 & 0 & 0 & 0 & 4 & 3 & 3 & 3 & 15 & 60 \\
\hline 18 & S18 & 0 & 1 & 0 & 1 & 0 & 3 & 4 & 3 & 2 & 14 & 56 \\
\hline 19 & S19 & 1 & 1 & 1 & 1 & 0 & 3 & 4 & 4 & 3 & 18 & 72 \\
\hline 20 & S20 & 0 & 1 & 1 & 1 & 0 & 4 & 4 & 4 & 3 & 18 & 72 \\
\hline 21 & S21 & 0 & 1 & 1 & 1 & 1 & 4 & 4 & 4 & 4 & 20 & 80 \\
\hline 22 & S22 & 1 & 1 & 1 & 0 & 1 & 3 & 3 & 3 & 3 & 16 & 64 \\
\hline 23 & S23 & 0 & 1 & 1 & 1 & 0 & 3 & 3 & 4 & 3 & 16 & 64 \\
\hline 24 & S24 & 1 & 1 & 0 & 1 & 1 & 4 & 2 & 3 & 2 & 15 & 60 \\
\hline 25 & S25 & 1 & 1 & 1 & 1 & 1 & 4 & 4 & 4 & S & 22 & 88 \\
\hline & & & & & Total & & & & $\mathbf{1 7 3 0}$ \\
\hline & & & & & & & & & & & \\
\hline
\end{tabular}

Tabel 3. Hasil belajar siswa siklus I

Data diatas menunjukkan bahwa pada siklus I hasil belajar siswa belum mencapai Kriteria Ketuntasan Minimal. Karena itu dilanjutkan pada siklus II. 
HASIL SIKLUS II

Tabel 4. Data Hasil Observasi Guru Siklus II

\begin{tabular}{|c|l|c|}
\hline No. & \multicolumn{1}{|c|}{ Aspek yang diamati } & Nilai \\
\hline 1. & Keterampilan menstimulasi siswa dalam pembelajaran (Stimulation) & 4 \\
\hline 2. & $\begin{array}{l}\text { Keterampilan membimbing siswa untuk membuat hipotesis tentang materi } \\
\text { pembelajaran yang sedang didalami (problem statement) }\end{array}$ & 4 \\
\hline 3. & $\begin{array}{l}\text { Keterampilan membimbing siswa dalam menemukan data-data dalam } \\
\text { pembelajaran (data collection) }\end{array}$ & 4 \\
\hline 4. & $\begin{array}{l}\text { Keterampilan membimbing siswa dalam mengolah data yang ditemukan (data } \\
\text { processing) }\end{array}$ & 4 \\
\hline 5. & $\begin{array}{l}\text { Keterampilan membimbing siswa membuktikan temuan data yang diperoleh } \\
\text { (verification) }\end{array}$ & 5 \\
\hline 6. & $\begin{array}{l}\text { Keterampilan membimbing siswa membuat kesimpulan dari data yang } \\
\text { diperoleh (generalization) }\end{array}$ & 4 \\
\hline 7. & Keterampilan membimbing siswa menyampaikan ide/gagasan/kesimpulan & 4 \\
\hline & \multicolumn{1}{|c|}{ Jumlah Skor Total } & $\mathbf{2 9}$ \\
\hline
\end{tabular}

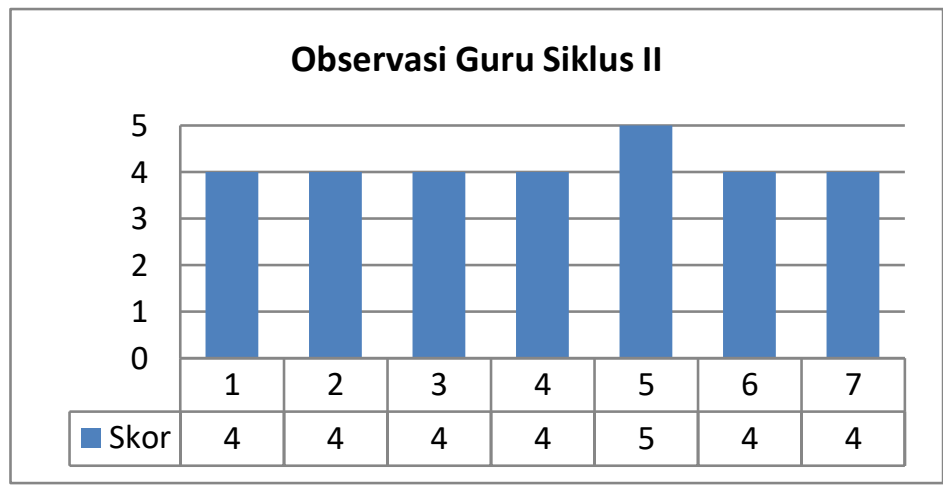

Gambar 3. Diagram Hasil Observasi Guru Siklus II

Data observasi guru siklus II menunjukkan bahwa persentasi keterampilan guru adalah: $29 / 35 \times 100 \%=82,85 \%$. Melihat data ini dapat dikatakan bahwa proses pembelajaran IPA di kelas dengan model Discovery Learning pada siklus II termasuk dalam kriteria B (Baik).

Selanjutnya, pada siklus II hasil belajar siswa dipersentasikan sebagai berikut:

$2040 / 2500 \times 100 \%=81,60 \%$. Hasil belajar ini mendapat kriteria 'Baik'. Berdasarkan hasil perbaikan belajar pada siklus II dalam pembelajaran IPA melalui penerapan model Discovery Learning dapat diperoleh data sebagai berikut:

\begin{tabular}{|c|l|c|}
\hline No & \multicolumn{1}{|c|}{ Aspek } & Pencapaian \\
\hline 1 & Nilai rata-rata yang dicapai & 81,60 \\
\hline 2 & Nilai terendah & 72 \\
\hline 3 & Nilai tertinggi & 96 \\
\hline 4 & Jumlah siswa tuntas & 22 \\
\hline 5 & Jumlah siswa tidak tuntas & 3 \\
\hline
\end{tabular}

Tabel 5. Rekapitulasi hasil belajar siklus II 
Berikut tabel hasil belajar siswa siklus II

\begin{tabular}{|c|c|c|c|c|c|c|c|c|c|c|c|c|}
\hline \multirow{2}{*}{ No } & \multirow{2}{*}{$\begin{array}{l}\text { Kode } \\
\text { Siswa }\end{array}$} & \multicolumn{9}{|c|}{ Skor Mentah } & \multirow{2}{*}{ Skor } & \multirow{2}{*}{ Nilai } \\
\hline & & 1 & 2 & 3 & 4 & 5 & 6 & 7 & 8 & 9 & & \\
\hline 1 & S1 & 1 & 1 & 1 & 1 & 0 & 4 & 5 & 3 & 4 & 20 & 80 \\
\hline 2 & $\mathrm{~S} 2$ & 0 & 1 & 1 & 1 & 1 & 4 & 4 & 4 & 4 & 20 & 80 \\
\hline 3 & S3 & 1 & 1 & 1 & 0 & 1 & 5 & 4 & 4 & 4 & 21 & 84 \\
\hline 4 & $\mathrm{~S} 4$ & 1 & 1 & 1 & 1 & 1 & 5 & 5 & 4 & 4 & 23 & 92 \\
\hline 5 & S5 & 1 & 1 & 1 & 1 & 1 & 3 & 4 & 4 & 4 & 22 & 88 \\
\hline 6 & S6 & 0 & 1 & 1 & 1 & 1 & 4 & 4 & 5 & 4 & 21 & 84 \\
\hline 7 & S7 & 1 & 1 & 1 & 1 & 1 & 4 & 4 & 4 & 4 & 21 & 84 \\
\hline 8 & $\mathrm{~S} 8$ & 0 & 1 & 1 & 1 & 1 & 4 & 3 & 4 & 4 & 19 & 76 \\
\hline 9 & S9 & 1 & 1 & 1 & 1 & 0 & 4 & 4 & 5 & 4 & 21 & 84 \\
\hline 10 & $\mathrm{~S} 10$ & 1 & 1 & 1 & 1 & 1 & 4 & 4 & 3 & 4 & 20 & 80 \\
\hline 11 & $\mathrm{~S} 11$ & 1 & 1 & 1 & 1 & 1 & 3 & 3 & 3 & 4 & 18 & 72 \\
\hline 12 & $\mathrm{~S} 12$ & 1 & 1 & 1 & 1 & 1 & 3 & 3 & 4 & 4 & 19 & 76 \\
\hline 13 & S13 & 1 & 1 & 1 & 1 & 1 & 4 & 4 & 5 & 4 & 22 & 88 \\
\hline 14 & S14 & 1 & 1 & 1 & 1 & 1 & 3 & 3 & 3 & 4 & 18 & 72 \\
\hline 15 & $\mathrm{~S} 15$ & 0 & 1 & 1 & 1 & 1 & 3 & 3 & 4 & 3 & 17 & 68 \\
\hline 16 & S16 & 1 & 0 & 1 & 1 & 1 & 3 & 4 & 4 & 5 & 20 & 80 \\
\hline 17 & $\mathrm{~S} 17$ & 1 & 1 & 1 & 1 & 0 & 4 & 3 & 5 & 5 & 21 & 84 \\
\hline 18 & $\mathrm{~S} 18$ & 1 & 1 & 1 & 1 & 1 & 4 & 4 & 4 & 4 & 21 & 84 \\
\hline 19 & S19 & 1 & 1 & 1 & 1 & 1 & 4 & 5 & 4 & 4 & 22 & 88 \\
\hline 20 & S20 & 0 & 1 & 1 & 1 & 1 & 4 & 4 & 4 & 3 & 19 & 76 \\
\hline 21 & S21 & 0 & 1 & 1 & 1 & 1 & 4 & 4 & 4 & 4 & 20 & 80 \\
\hline 22 & $\mathrm{~S} 22$ & 1 & 1 & 1 & 1 & 1 & 3 & 5 & 3 & 5 & 21 & 84 \\
\hline 23 & S23 & 0 & 1 & 1 & 1 & 1 & 3 & 3 & 5 & 5 & 20 & 80 \\
\hline 24 & S24 & 1 & 1 & 0 & 1 & 1 & 4 & 5 & 3 & 4 & 20 & 80 \\
\hline 25 & $\mathrm{~S} 25$ & 1 & 1 & 1 & 1 & 1 & 4 & 5 & 5 & 5 & 22 & 96 \\
\hline & & & & & & otal & & & & & & 2040 \\
\hline
\end{tabular}

Tabel 6. Hasil belajar siswa siklus II

Hasil penelitian siklus II menunjukkan bahwa hasil belajar siswa telah mencapai Kriteria Ketuntasan Minimal. karena itu, penelitian ini dapat dihentikan.

\section{PEMBAHASAN}

Pada siklus I hal yang diamati adalah mengenai keterampilan guru dalam menerapkan model discovery learning dan hasil belajar siswa kelas V SD Katolik St. Paulus Kembes. Menurut hasil yang telah dipaparkan di atas, keterampilan guru dalam menggunakan model discovery learning adalah sebesar 71,42\% dengan kriteria Baik. Dalam proses belajar mengajar dengan model discovery learning, pada tahap stimulasi, guru dapat mengarahkan siswa untuk tertuju pada proses yang akan dilalui bersama. Namun pada tahap-tahap sesudahnya, ada beberapa catatan kritis yang ditemukan dalam proses pembelajaran siklus I, antara lain: guru masih kelihatan kesulitan terutama dalam membantu siswa pada tahap penyampaian masalah (problem statement). Model discovery learning mewajibkan guru menjadi fasilitator dan siswa dengan sendirinya menemukan dan mengungkapkan masalah, sampai pada 
pembentukan hipotesis. Pada tahap ini guru kesulitan untuk memfasilitasi anak agar membuat hipotesis yang sesuai dengan sifat-sifat cahaya yang hendak ditemukan.

Selanjutnya, kemampuan setiap siswa ternyata berbeda-beda satu dengan yang lain. Pada siklus I ini guru belum memahami kemampuan setiap siswa dalam pembelajaran. Hal ini menyebabkan proses pembelajaran tidak berjalan dengan lancar. Para siswa yang memiliki kemampuan baik, akan lebih dahulu menyelesaikan langkah-langkah pembelajaran, sedangkan siswa yang memiliki kemampuan rendah sangat kesulitan dan lambat dalam mengikuti proses yang sudah direncanakan. Hal ini benar-benar terlihat pada tahap verifikasi dan generalisasi dalam model discovery learning. Pada tahap ini guru kesulitan untuk membimbing siswa dalam membuat verifikasi dan generalisasi sesudah siswa memperhatikan tayangan LCD. Guru kesulitan untuk mengarahkan siswa menyampaikan kesimpulan-kesimpulan yang ditemui dalam pembelajaran. Hasil kesimpulan yang diutarakan sangat ditentukan oleh intensitas pendampingan dan arahan guru. Siswa masih kesulitan untuk merumuskan ide/gagasannya sendiri. Guru masih perlu memahami kemampuan siswa dan lebih intensif dalam mengarahkan dan membimbing siswa agar kegiatan dapat berjalan dengan lancar.

Indikator-indikator yang ditentukan pada materi sifat-sifat cahaya adalah siswa mampu menjelaskan tentang beberapa sifat cahaya, yakni: cahaya dapat merambat menurut garis lurus dan cahaya dapat dibiaskan. pada siklus I terlihat jelas bahwa tingkat pemahaman siswa terhadap konsep dan kosakata juga mempengaruhi proses pembelajaran dengan model discovery learning. Pada siklus I ditemukan bahwa para siswa tidak mengerti tentang beberapa kosakata penting, yakni "merambat", "hipotesis", dan "dibiaskan". pada bagian kesimpulan, ketika guru memberikan kesimpulan dan penguatan ternyata hampir seluruh siswa kelas V SD Katolik St. Paulus Kembes tidak bisa memahami dan menjelaskan tentang dua kosakata tersebut. Padahal, dua kata tersebut merupakan kata kunci untuk menemukan sifat-sifat cahaya. Guru perlu memberikan penjelasan khusus untuk beberapa kosakata yang sulit untuk dipahami dan dicerna siswa sehingga proses discovery learning dapat berjalan dengan baik, dalam arti bahwa siswa dapat menemukan dan menyimpulkan sifat-sifat cahaya yang hendak dicari.

Hal berikut yang perlu diperhatikan pada siklus I adalah penggunaan media pembelajaran dalam proses pembelajaran. Media pembelajaran sangat penting dalam membantu guru menyampaikan materi pembelajaran dan juga membantu siswa lebih memahami materi yang disampaikan guru. Pada siklus I ini guru memilih media Laptop dan LCD sebagai sarana untuk pembelajaran. Materi sifat-sifat cahaya disajikan melalui power point yang sudah disiapkan guru dan ditampilkan dalam LCD. Awalnya para siswa tertarik untuk memperhatikan, namun setelah diputar berulang-ulang (pada fase mengumpulkan data dan verifikasi) para siswa kelihatan sudah bosan dan tidak fokus. Dengan hanya menggunakan LCD yang ditayangkan berulang-ulang, Nampak jelas bahwa para siswa tidak dapat sepenuhnya mengikuti seluruh proses yang ditawarkan dalam model discovery learning. Hal ini juga berhubungan dengan kemampuan masing-masing siswa yang berbeda-beda. Penggunaan media laptop dan LCD belum efektif membantu seluruh siswa untuk mengikuti seluruh proses dalam discovery learning dan menemukan sendiri pengetahuan yang diharapkan tentang topik sifat-sifat cahaya.

Beberapa catatan di atas ternyata sangat mempengaruhi hasil belajar siswa setelah guru menerapkan model discovery learning dalam proses belajar mengajar. Pada siklus I persentasi hasil belajar siswa adalah sebesar $40 \%$ dengan jumlah siswa yang memenuhi 
kriteria ketuntasan minimal sebanyak 10 orang saja. Memang, pada tahap pra siklus, persentasi hasil belajar siswa hanya sebesar 30\% dengan jumlah siswa yang tuntas sebanyak 8 orang. Hal ini berarti bahwa terjadi peningkatan hasil belajar siswa sebanyak $10 \%$. Namun, secara keseluruhan masih terdapat $60 \%$ siswa yang belum tuntas atau sebanyak 15 siswa belum sesuai dengan kriteria ketuntasan minimal. beberapa penjelasan di atas menjelaskan dengan rinci penyebab masih rendahnya hasil belajar siswa pada siklus I ini. oleh karena itu, peneliti melanjutkan pada siklus berikutnya.

Pada siklus II ini peneliti memperhatikan beberapa catatan penting pada siklus I dan kemudian merancang pelaksanaan pembelajaran dengan model discovery learning. Pada siklus II ini hasil penelitian menunjukkan terjadi peningkatan keterampilan guru dalam menerapkan model discovery learning dan peningkatan hasil belajar siswa setelah diterapkan model discovery learning. Pada siklus II ini, persentasi keterampilan guru dalam menerapkan model discovery learning adalah sebesar $82,85 \%$ dengan kriteria 'baik'. Data ini menunjukkan bahwa terjadi peningkatan sebesar 11,44\%. Meskipun masih dalam kriteria 'baik' namun telah terjadi peningkatan performa guru. Hasil belajar siswa pada siklus II memperoleh persentasi sebesar $81 \%$. Hal ini berarti bahwa telah terjadi peningkatan hasil belajar siswa secara signifikan setelah guru menerapkan model discovery learning. Peningkatan persentasi hasil belajar siswa dari siklus I ke siklus II adalah sebesar $40 \%$. Pada siklus II ini sebanyak 22 siswa dinyatakan memenuhi kriteria ketuntasan minimal, dan hanya 3 orang siswa saja yang tidak tuntas hasil belajarnya. Hal ini tidak lepas dari beberapa perubahan yang dibuat oleh guru mengacu dari beberapa kelemahan pada siklus I.

Pada siklus II ini guru merancang pembelajaran dengan membuat kegiatan eksperimen untuk menemukan tiga sifat cahaya lainnya, yakni: cahaya dapat dipantulkan, cahaya dapat menembus benda bening, dan cahaya dapat diuraikan. Guru menyiapkan bahan dan alat yang diperlukan untuk kegiatan eksperimen dan menyiapkan lembar kerja siswa. Kegiatan eksperimen dibuat dalam kelompok (terdiri dari 3 kelompok) untuk menemukan sifat-sifat cahaya tersebut. Pembentukan kelompok juga dimaksudkan agar para siswa dapat saling membantu dalam menemukan pengetahuan yang diharapkan. Setiap kelompok dibentuk setelah berkoordinasi dengan guru kelas/kolaborator dengan memperhatikan kemampuan masing-masing siswa agar tercipta keseimbangan.

Selain skenario pembelajaran yang dirancang secara berbeda, guru juga sengaja menulis di papan tulis beberapa kosakata yang sulit yang berhubungan dengan materi yang diajarkan, antara lain tentang "pemantulan", "benda bening", dan "penguraian". Kata-kata ini kemudian juga dijelaskan secara gamblang pada awal pembelajaran tanpa menghubungkannya dengan sifat-sifat cahaya. Hal ini dibuat untuk memfasilitasi siswa mengidentifikasi masalah yang ditemukan dalam eksperimen dan merumuskan hipotesis secara benar.

Kegiatan pembelajaran dengan eksperimen berkelompok membantu siswa dalam menemukan sifat-sifat cahaya sesuai dengan sintaks pada model discovery learning. Pada siklus II ini seluruh kelompok dapat menemukan sifat-sifat cahaya yang hendak dicari. Hal ini dimungkinkan karena para siswa membuat eksperimen berulang-ulang dalam kelompok menggunakan bahan dan alat yang sudah disiapkan. Guru memfasilitasi dan memotivasi siswa untuk mengikuti langkah-langkah dalam eksperimen. Pada saat-saat tertentu guru bersama dengan siswa dalam kelompok dan membantu mereka dalam berekperimen. Seluruh temuan siswa dapat ditulis dalam lembar kerja yang telah disiapkan. Kemudian, setelah proses pengumpulan data, dan pengolahan data selesai, guru mengajak siswa 
memverifikasi dan membuat generalisasi tentang sifat-sifat cahaya yang telah ditemukan. Pada tahap ini guru mengajak masing-masing kelompok tampil ke depan kelas, membawa bahan dan alatnya dan menjelaskan temuan mereka dengan bukti-buktinya. Pada tahap ini terlihat semua siswa terlibat dalam pembelajaran. Ada yang menjelaskan, ada yang mencatat, dan ada pula yang menyiapkan bahan dan alat untuk dibuktikan di depan kelas. Pada bagian akhir, penulis membuat kesimpulan dan penguatan tentang pokok-pokok sifatsifat cahaya yang dipelajari. Untuk lebih menghidupkan suasana dan membuat siswa lebih cepat memahaminya, guru mengadakan games sederhana dengan judul "cepat dan tepat" menebak sifat-sifat cahaya.

Proses pembelajaran siklus II ini menjadi hidup dan efektif. Siswa terlihat menikmati dan aktif dalam keseluruhan proses pembelajaran dengan model discovery learning. Siswa dapat mengidentifikasi masalah, membuat hipotesis dengan pemahaman sendiri, menemukan dan mengolah data, memverifikasi dan membuat kesimpulan sesuai dengan data-data yang ditemukan secara mandiri. Guru mendampingi sebagai fasilitator yang mengarahkan agar siswa terlibat penuh dalam keseluruhan proses pembelajaran. Hal ini juga terungkap ketika peneliti mengevaluasi kegiatan pembelajaran siklus II ini dengan guru kelas/kolaborator. Dengan hasil pada siklus II yang telah mengalami peningkatan signifikan serta tingkat ketuntasan hasil belajar siswa melebihi kriteria ketuntasan minimal yang ditentukan, maka penulis tidak lagi melanjutkan ke siklus selanjutnya.

\section{KESIMPULAN}

Berdasarkan hasil penelitian pembelajaran IPA dengan menerapkan model Discovery Learning pada siswa kelas V SD Katolik St. Paulus Kembes dan pembahasannya, dapat ditarik beberapa kesimpulan sebagai berikut:

1. Model pembelajaran Discovery Learning dapat meningkatkan hasil belajar siswa kelas V SD Katolik St. Paulus kembes.

2. Keterampilan guru dalam menerapkan model pembelajaran Discovery Learning untuk mata pelajaran IPA pada siswa kelas V SD Katolik St. Paulus Kembes mengalami peningkatan.

\section{SARAN}

1. Guru kelas hendaknya dapat menggunakan model pembelajaran Discovery Learning dalam setiap kegiatan pembelajaran IPA demi peningkatan kualitas pembelajaran di sekolah.

2. Dalam penerapan pembelajaran model Discovery Learning para siswa hendaknya berperan aktif terutama dalam menemukan gagasan/ide dan mengungkapkannya dengan pemahaman original.

3. Penelitian tindakan melalui penerapan model Discovery Learning dapat dikembangkan lebih lanjut oleh guru, lembaga maupun siapa saja yang turut meningkatkan kualitas pendidikan sehingga model pembelajaran ini dapat menjadi lebih baik dan bermanfaat di masa yang akan datang.

\section{REFERENSI}

Abdullah Aly dan Eny Rahma, 2009. Ilmu Alamiah Dasar. Jakarta: PT Bumi Aksara. Abruscato, Joseph \& Derosa, Donald A. 2010. Teaching Children Science: A Discovery Approach. USA: Pearson.

Balim, Ali Gunay. 2009. The Effect of Discovery Learning on Students' Succes and Inquiry Learning Skills. Egitim Arastirmalary Eurasian Journal of Educational Research, $35,1-20$.

Budiningsih, C., Asri. 2010. Belajar dan Pembelajaran, Jakarta: PT Rineka Cipta 
Dewey, J. 2009. Democracy and Education: Pengantar Filsafat Pendidikan (edisi terjemahan). Jakarta: WLC. (pekerjaan asli diterbitkan tahun 1916).

Dimyati dan Mdjiono. 2009. Belajar dan Pembelajaran. Jakarta: PT Rineka Cipta

Ekawarna. 2013. Penelitian Tindakan Kelas, Edisi Revisi. Jakarta: Referensi GP Press Group.

Evi Nupita. 2013. Penerapan Model Pembelajaran Penemuan Terbimbing untuk meningkatkan Hasil Belajar dan Keterampilan Pemecahan Masalah IPA pada Siswa Kelas V Sekolah Dasar. Jurnal PGSD (Volume 1 Nomor 2 Tahun 2013, 0216)

Hamruni. 2012. Strategi Pembelajaran. Yogyakarta: Insan Madewi.

Haryono. 2013. Pembelajaran IPA yang Menarik dan Mengasyikkan: Teori dan Aplikasi PAIKEM. Yogyakarta: Kepel Press.

Putrayasa, Syaruddin dan Margunayasa. 2014. Pengaruh Model Pembelajaran Discovery Learning dan Minat Belajar terhadap Hasil Belajar IPA siswa. Jurnal Mimbar PGSD Universitas Pendidikan Ganesha (Volume 2 nomor 1, Tahun 2014).

Rohim, Fatur. dkk. 2012. Penerapan Model Discovery Terbimbing pada pembelajaran Fisika Untuk Meningkatkan Kemampuan Berpikir Kreatif. Unnes Physics Education Journal. Vol. 1 No. 1 (2012).

Samatowa, U. 2010. Pembelajaran IPA di Sekolah Dasar. Jakarta: Gramedia.

Slameto. 2003. Belajar dan Faktor-Faktor Yang Mempengaruhinya. Jakarta: Rineka Cipta.

Suprijono, Agus. 2011. Cooperative Learning. Yogyakarta: Pustaka Pelajar

Suwono, H. 2009. Dasar-Dasar Penilaian Hasil Belajar IPA. Surabaya: Putra Media Nusantara.

Syah. Muhibbin. 2004. Psikologi Pendidikan Dengan Pendekatan Baru. Bandung: Remaja Rosdakarya

Tim Pengembang Ilmu Pendidikan. 2007. Ilmu dan Aplikasi Pendidikan. Bandung: IMTIMA.

Trianto. 2007. Model Pembelajaran Terpadu dalam Teori dan Praktek. Jakarta: Prestasi Pustaka Publisher. 2011. Panduan Lengkap Penelitian Tindakan Kelas (Classroom Action Research) Teori dan Praktek. Jakarta: Prestasi Pustaka Publisher.

2012. Model Pembelajaran Terpadu, Konsep, Strategi, dan Implementasinya dalam Kurikulum Tingkat Satuan Pendidikan (KTSP). Jakarta: PT Bumi Aksara.

Wahidmurni, Alifin Mustikawan, dan Ali Ridho. 2010. Evaluasi Pembelajaran: Kompetensi dan Praktik. Yogyakarta: Nuha Letera.

Widiadnyana, Sadia dan Suastra. 2014. Pengaruh Model Discovery Learning terhadap Pemahaman Konsep IPA dan Sikap Ilmiah Siswa SD. E-jurnal Program Pascasarjana Universitas Pendidikan Ganesha Program Studi IPA (Volume 4 tahun 2014)

Winkel, WS. 1984. Psikologi Pendidikan dan Evaluasi Belajar. Jakarta: Gramedia.

Asyari, Helmi. 2014. "Penerapan Model Discovery Learning pada mata pelajaran IPA materi sifat-sifat cahaya untuk meningkatkan keterampilan proses sains siswa" PTK. (on line) http://repository.upi.edu/13846/.pdf.

Ishaq Madeamin. 2011. Model PTK "Model Spiral dari Kemmis dan Taggart" (on line) http://www.ishaqmadeamin.com/2012/11/model-ptk-3-model-spiral-darikemmis.html

Maulana, Sandi. 2014. "Penerapan Model Discovery Learning untuk meningkatkan keaktifan dan hasil belajar siswa pada mata pelajaran IPA materi pengaruh gaya terhadap gerak benda (PTK di SDN 1 Cibodas kelas IV, Kecamatan Lembang, 
Kabupaten Bandung Barat)" (on line)

http://repository.upi.edu/11707/3/S_PGSD_1003577_Abstract.pdf.

Nurhidayah, Lilis. 2014. "Penerapan Model Discovery Learning untuk meningkatkan pembelajaran konsep sifat-sifat cahaya di kelas V SDN 2 Suntenjaya Kecamatan Lembang, Kabupaten Bandung Barat" PTK. (on line) http://repository.upi.edu/12220/pdf.

Sulbani, Slamet. 2014. "Upaya Peningkatan Prestasi Belajar IPA dengan Pendekatan Discovery Learning pada siswa kelas IV MI Muhammadiah Nogosari Girimulyo, Kulon Progo, Yogyakarta” PTK. (on line) http://digilib.uin-suka.ac.id/14046/pdf. 